NASA/TM-2006-213983

\title{
Status of a Power Processor for the Prometheus-1 Electric Propulsion System
}

Luis R. Piñero and Gerald M. Hill

Glenn Research Center, Cleveland, Ohio

Michael Aulisio, Scott Gerber, Elmer Griebeler, Frank Hewitt, and Joseph Scina

ZIN Technologies, Inc., Brook Park, Ohio 
Since its founding, NASA has been dedicated to the advancement of aeronautics and space science. The NASA Scientific and Technical Information (STI) Program Office plays a key part in helping NASA maintain this important role.

The NASA STI Program Office is operated by Langley Research Center, the Lead Center for NASA's scientific and technical information. The NASA STI Program Office provides access to the NASA STI Database, the largest collection of aeronautical and space science STI in the world. The Program Office is also NASA's institutional mechanism for disseminating the results of its research and development activities. These results are published by NASA in the NASA STI Report Series, which includes the following report types:

- $\quad$ TECHNICAL PUBLICATION. Reports of completed research or a major significant phase of research that present the results of NASA programs and include extensive data or theoretical analysis. Includes compilations of significant scientific and technical data and information deemed to be of continuing reference value. NASA's counterpart of peerreviewed formal professional papers but has less stringent limitations on manuscript length and extent of graphic presentations.

- TECHNICAL MEMORANDUM. Scientific and technical findings that are preliminary or of specialized interest, e.g., quick release reports, working papers, and bibliographies that contain minimal annotation. Does not contain extensive analysis.

- CONTRACTOR REPORT. Scientific and technical findings by NASA-sponsored contractors and grantees.
- CONFERENCE PUBLICATION. Collected papers from scientific and technical conferences, symposia, seminars, or other meetings sponsored or cosponsored by NASA.

- SPECIAL PUBLICATION. Scientific, technical, or historical information from NASA programs, projects, and missions, often concerned with subjects having substantial public interest.

- TECHNICAL TRANSLATION. Englishlanguage translations of foreign scientific and technical material pertinent to NASA's mission.

Specialized services that complement the STI Program Office's diverse offerings include creating custom thesauri, building customized databases, organizing and publishing research results ... even providing videos.

For more information about the NASA STI Program Office, see the following:

- Access the NASA STI Program Home Page at http://www.sti.nasa.gov

- E-mail your question via the Internet to help@sti.nasa.gov

- Fax your question to the NASA Access Help Desk at 301-621-0134

- Telephone the NASA Access Help Desk at 301-621-0390

- Write to:

NASA Access Help Desk

NASA Center for AeroSpace Information 7121 Standard Drive

Hanover, MD 21076 
NASA/TM-2006-213983

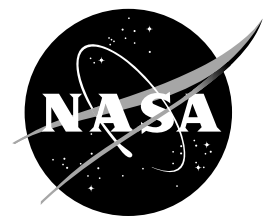

\section{Status of a Power Processor for the Prometheus-1 Electric Propulsion System}

Luis R. Piñero and Gerald M. Hill

Glenn Research Center, Cleveland, Ohio

Michael Aulisio, Scott Gerber, Elmer Griebeler, Frank Hewitt, and Joseph Scina ZIN Technologies, Inc., Brook Park, Ohio

Prepared for the

41st Joint Propulsion Conference and Exhibit cosponsored by AIAA, ASME, SAE, and ASEE

Tucson, Arizona, July 10-13, 2005

National Aeronautics and

Space Administration

Glenn Research Center 
Available from

NASA Center for Aerospace Information 7121 Standard Drive

Hanover, MD 21076
National Technical Information Service 5285 Port Royal Road Springfield, VA 22100

Available electronically at http://gltrs.grc.nasa.gov 


\title{
Status of a Power Processor for the Prometheus-1 Electric Propulsion System
}

\author{
Luis R. Piñero and Gerald M. Hill \\ National Aeronautics and Space Administration \\ Glenn Research Center \\ Cleveland, Ohio 44135 \\ Michael Aulisio, Scott Gerber, Elmer Griebeler, Frank Hewitt, and Joseph Scina \\ ZIN Technologies, Inc. \\ Brook Park, Ohio 44142
}

\begin{abstract}
NASA is developing technologies for nuclear electric propulsion for proposed deep space missions in support of the Exploration initiative under Project Prometheus. Electrical power produced by the combination of a fission-based power source and a Brayton power conversion and distribution system is used by a high specific impulse ion propulsion system to propel the spaceship. The ion propulsion system includes the thruster, power processor and propellant feed system. A power processor technology development effort was initiated under Project Prometheus to develop high performance and lightweight power-processing technologies suitable for the application. This effort faces multiple challenges including developing radiation hardened power modules and converters with very high power capability and efficiency to minimize the impact on the power conversion and distribution system as well as the heat rejection system. This paper documents the design and test results of the first version of the beam supply, the design of a second version of the beam supply and the design and test results of the ancillary supplies.
\end{abstract}

\section{Introduction}

Prior power processing unit (PPU) developments for ion thrusters were targeted for solar electric propulsion (SEP) applications. NASA's Solar electric propulsion Technology Application Readiness (NSTAR) and NASA's Evolutionary Xenon Thruster (NEXT) programs developed PPUs for a direct current (DC) power bus. These PPUs consisted of multiple DC-to-DC converters to process power into the voltages and currents required by the thrusters. The maximum amount of power processed by this kind of PPU has been approximately $7.0 \mathrm{~kW}$ with efficiency no higher than 95 percent and the specific mass no lower than $4.5 \mathrm{~kg} / \mathrm{kW}$. DC PPUs are highly complex and contain thousands of parts that result in decreased reliability. ${ }^{1-2}$

As part of NASA's Exploration Initiative, Project Prometheus is developing technologies for nuclear electric propulsion (NEP) for proposed deep space mission. ${ }^{3}$ The proposed NEP system consists of a fission-based power source, a Brayton-based power conversion and distribution system (PCAD) and an ion propulsion system. The ion $\mathrm{kW}$ ion thruster with carbon-based grids is being developed in a joint effort between NASA GRC and JPL under the Herakles program. This thruster must be capable of 70,000 hours of operation to meet the requirements for many possible missions for Project Prometheus starting with the proposed Jupiter Icy Moons Orbiter (JIMO) mission to be flown by the Prometheus-1 spaceship. ${ }^{4}$

The goal of the Prometheus power processor technology development effort is to develop power-processing technologies suitable for the Herakles ion thruster and the Brayton PCAD. This effort faces multiple challenges, including developing power modules and converters with very high power capability and efficiency, to minimize the 
impact on the power conversion and distribution system (PCAD) and the heat rejection system. Also, it must be lightweight to minimize the EP system dry mass and capable of surviving challenging environmental requirements including intense radiation. Finally, it must be a relatively simple design for high reliability. Requirements for the power processor unit were derived from Prometheus-1 spaceship mission requirements..$^{5}$

A breadboard consisting of beam and accelerator supplies was designed and fabricated. ${ }^{6}$ These supplies process high voltage and most of the power for the engine and can be stressed by engine short circuits or "recycles". The breadboard was going to be used to validate the transformer/rectifier architecture and to characterize engine recycles. However, due to programmatic issues, the test could not be done with a laboratory thruster, so a simulated load was used instead. The results of these tests are presented in this paper.

While the breadboard beam and accelerator supplies were being built, some power semiconductors selected for the design were deemed unsuitable for the Prometheus-1 radiation environment. Also, specifications for the operating frequency of the PCAD system and the output voltage of the beam supply were changed. Being close to completion, it was decided to continue work on the beam and accelerator supplies and use them for validation testing. The beam supply was then redesigned with a completely new approach using only recommended parts and transformers for the new PCAD frequency. Finally, the DC-DC converters for the accelerator grid and the cathode functions were also designed. This paper documents the design and testing of the first version beam supply and its integration with the accelerator supply and testing with a simulated load. It also documents the design changes for the second version of the beam supply and the design of the ancillary supplies.

\section{Power Processor Specifications and Configuration}

An ion propulsion power processor is required to provide six distinct electrical outputs, with various levels of voltage and current for different functions of the thruster. The beam supply is the dominant supply in the power processor, as it processes more than $96 \%$ of the total power and provides high voltage in combination with the accelerator supply to accelerate ions. These ions are created by the discharge cathode, which is fed by a constant current from the discharge supply. The neutralizer cathode provides a "plasma bridge" for discharge electrons to neutralize the ion beam. This cathode is operated with a constant current from the neutralizer keeper supply. Finally, both cathodes require a heater supply for ignition. The power processor also contains a housekeeping power supply and data control and interface circuitry that communicates with the spacecraft and controls the power converter and modules.

A Brayton PCAD provides the input power for the Prometheus-1 power processor. The original requirements for the input to the power processor were 3-phase $400 \pm 40 \mathrm{Vac}$ and a frequency of 1.0 to $1.5 \mathrm{kHz}$. $^{7}$ The frequency was subsequently changed to $2.25 \mathrm{kHz}$ because of changes in PCAD design. The frequency variation of the PCAD system is expected to be less than 1 percent.

Table 1. Prometheus-1 power processor requirements

\begin{tabular}{|c|c|c|c|c|c|c|c|c|c|}
\hline & NSTAR & NEXT & $\begin{array}{c}\text { P1 } \\
\text { (Prelim) }\end{array}$ & P1 & & NSTAR & NEXT & $\begin{array}{c}\text { P1 } \\
\text { (Prelim) }\end{array}$ & P1 \\
\hline $\begin{array}{c}\text { Input } \\
\text { Voltage }\end{array}$ & $\begin{array}{l}80-160 \\
V_{D C}\end{array}$ & $\begin{array}{l}80-160 \\
V_{D C}\end{array}$ & $\begin{array}{l}\text { 3-phase } \\
360-440 \mathrm{Vac}\end{array}$ & $\begin{array}{l}\text { 3-phase } \\
360-440 \mathrm{Vac}\end{array}$ & Beam & $\begin{array}{l}1100 \mathrm{~V} \\
1.7 \mathrm{~A}\end{array}$ & $\begin{array}{l}1800 \mathrm{~V} \\
3.5 \mathrm{~A}\end{array}$ & $\begin{array}{l}6500 \mathrm{~V} \\
3.8 \mathrm{~A}\end{array}$ & $\begin{array}{l}4600 \mathrm{~V} \\
6.0 \mathrm{~A}\end{array}$ \\
\hline $\begin{array}{l}\text { Output } \\
\text { Power }\end{array}$ & $2.3 \mathrm{~kW}$ & $6.9 \mathrm{~kW}$ & $25 \mathrm{~kW}$ & $29 \mathrm{~kW}$ & Accel. & $\begin{array}{l}250 \mathrm{~V} \\
20 \mathrm{~mA}\end{array}$ & $\begin{array}{l}400 \mathrm{~V} \\
50 \mathrm{~mA}\end{array}$ & $\begin{array}{l}800 \mathrm{~V} \\
50 \mathrm{~mA}\end{array}$ & $\begin{array}{l}732 \mathrm{~V} \\
50 \mathrm{~mA}\end{array}$ \\
\hline Efficiency & $\leq 94 \%$ & $\leq 95 \%$ & $\geq 96 \%$ & $\geq 96 \%$ & Disch. & $\begin{array}{l}35 \mathrm{~V} \\
15 \mathrm{~A}\end{array}$ & $\begin{array}{l}35 \mathrm{~V} \\
24 \mathrm{~A}\end{array}$ & $\begin{array}{l}35 \mathrm{~V} \\
30 \mathrm{~A}\end{array}$ & $\begin{array}{l}35 \mathrm{~V} \\
52 \mathrm{~A}\end{array}$ \\
\hline Frequency & $20 \mathrm{kHz}$ & $50 \mathrm{kHz}$ & $\begin{array}{l}1.00-1.50 \\
\mathrm{kHz}\end{array}$ & $2.25 \mathrm{kHz}$ & Neut. & $\begin{array}{l}32 \mathrm{~V} \\
2.0 \mathrm{~A}\end{array}$ & $\begin{array}{l}32 \mathrm{~V} \\
3.0 \mathrm{~A}\end{array}$ & $\begin{array}{l}35 \mathrm{~V} \\
3.0 \mathrm{~A}\end{array}$ & $\begin{array}{l}35 \mathrm{~V} \\
5.5 \mathrm{~A}\end{array}$ \\
\hline $\begin{array}{c}\text { Specific } \\
\text { Mass }\end{array}$ & $\begin{array}{l}6 \\
\mathrm{~kg} / \mathrm{kW}\end{array}$ & $\begin{array}{l}4.5 \\
\mathrm{~kg} / \mathrm{kW}\end{array}$ & $<3 \mathrm{~kg} / \mathrm{kW}$ & $<3 \mathrm{~kg} / \mathrm{kW}$ & $\begin{array}{l}\text { Disch. } \\
\text { Heater }\end{array}$ & $\begin{array}{l}12 \mathrm{~V} \\
8.5 \mathrm{~A}\end{array}$ & $\begin{array}{l}24 \mathrm{~V} \\
8.5 \mathrm{~A}\end{array}$ & $\begin{array}{l}24 \mathrm{~V} \\
8.5 \mathrm{~A}\end{array}$ & $\begin{array}{l}24 \mathrm{~V} \\
8.5 \mathrm{~A}\end{array}$ \\
\hline Radiation & $\begin{array}{l}100 \\
\text { KRad }\end{array}$ & $\begin{array}{l}100 \\
\text { KRad }\end{array}$ & $\begin{array}{l}6 \text { MRad } \\
\text { (box) } \\
500 \mathrm{kRad} \\
\text { (parts) }\end{array}$ & $\begin{array}{l}6 \text { MRad } \\
\text { (box) } \\
500 \mathrm{kRad} \\
\text { (parts) }\end{array}$ & $\begin{array}{l}\text { Neut. } \\
\text { Heater }\end{array}$ & $\begin{array}{l}12 \mathrm{~V} \\
8.5 \mathrm{~A}\end{array}$ & $\begin{array}{l}12 \mathrm{~V} \\
8.5 \mathrm{~A}\end{array}$ & $\begin{array}{l}24 \mathrm{~V} \\
8.5 \mathrm{~A}\end{array}$ & $\begin{array}{l}24 \mathrm{~V} \\
8.5 \mathrm{~A}\end{array}$ \\
\hline
\end{tabular}


Table 1 summarizes preliminary and updated input and output specifications for the Prometheus-1 power processor in comparison to the NSTAR and NEXT PPUs. After completing trade studies on architectures for the power processor, an AC-DC supply with simple transformer/rectifier modules was chosen for the beam supply. This concept was previously demonstrated, but only with an NSTAR thruster operating at $1.0 \mathrm{~kW}$ and $1100 \mathrm{~V}$. Significantly higher power and voltage levels and a new thruster and PCAD system for Prometheus-1 required additional validation of the power processor design to reduce risk. For the other power supplies, DC-DC converters fed from a separate transformer/rectifier were chosen. Since these power converters process a small fraction of the power, their mass impact will be negligible while maintaining the heritage of prior ion propulsion PPUs of using DC-DC converters for these functions. Power semiconductors for both transformer/rectifier modules and DC-DC converters were selected based on their potential to meet radiation requirements. They were derated using project guidelines of 70 percent for voltage and 50 percent for current and power. Figure 1 shows a block diagram of the Prometheus-1 power processor including power and control interfaces.

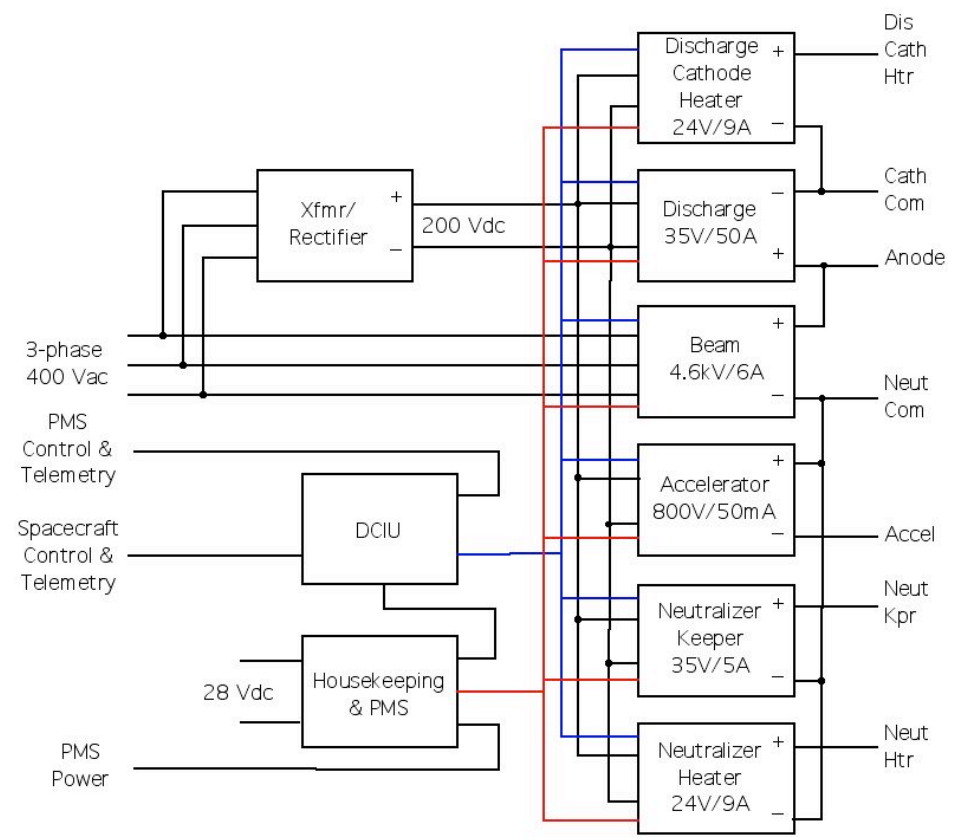

Figure 1. Block diagram of Prometheus-1 power processor

\section{Beam Supply}

\section{A. Design}

For prior ion PPU designs, the beam supply consisted of DC-DC converters. These highly complex PPUs contained thousands of parts and demonstrated efficiencies no higher than 95 percent. Because of the power level processed by the Prometheus-1 power processor, radiation levels, the high reliability expected from the EP subsystem and the availability of an AC power bus, it was decided to use series of transformer/rectifier modules where the transformers amplify the AC input voltage while the rectifier changes it into DC power. This not only results in a simpler circuit with fewer parts, but also higher efficiency because it has fewer losses than a DC-DC converter. One drawback to this approach is that the transformers will be larger that those of a DC-DC converter because the operating frequency of $1.0 \mathrm{kHz}$ is much lower than in DC-DC converters. A system design benefit is that the additional transformer mass can aid in shielding for radiation the sensitive electronics in the power processor. Trade studies compared the mass of a power processor with transformer/rectifiers and the DC-DC converter approach including radiation shields. It was concluded that the transformer/rectifier approach would have a possible mass and efficiency advantage. The advantage was even more pronounced when the frequency was increased to $2.25 \mathrm{kHz}$.

Carbon-based grids have been baselined for the Herakles ion thruster. Prior investigations have demonstrated that carbon-based grids are susceptible to charge transfer. ${ }^{9}$ Excessive charge deposition on the grids during a fault can damage the grid material, reducing thruster life and performance. A significant fraction of the stored charge is in the 
output filter capacitor of the beam supply. One design priority for the beam supply was to minimize the amount of stored charge including the size of the output capacitor.

Twelve-pulse rectification was used for the beam supply modules. This technique uses two 3-phase rectifiers with different delta and wye connections to produce a 30-degree phase-shift of the voltage between transformer/rectifier sets. Figure 2 depicts a 3-phase vector diagram showing the phase-shift between a delta-delta and a delta-wye transformer. After the voltage is rectified, it results in a waveform with 12 maxima instead of 6 for the typical 3-phase rectifier. As a result, a smaller output capacitor is then needed to meet output ripple specifications.
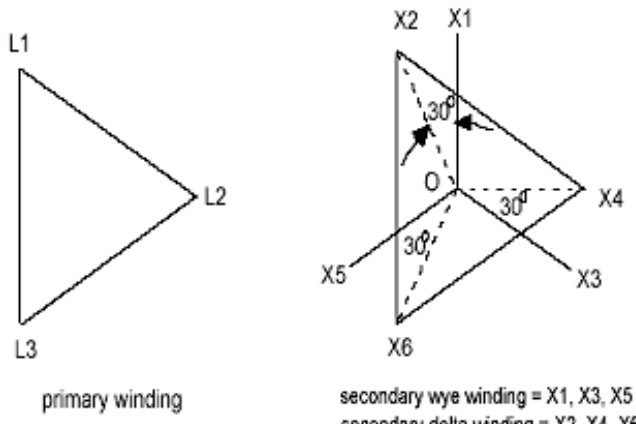

secondary wye winding $=X 1, X_{3}, X_{5}$ secondary delta winding $=X 2, X 4, X 6$

Two different types of 12-pulse rectification modules were used to fabricate the beam supply. Unregulated rectification modules with diode rectifiers were used because of their simplicity and high efficiency. Controlled rectification modules were also used to provide voltage regulation to compensate for input voltage variations and to throttle the engine power. This module has the same design as the unregulated modules but instead of diodes it uses silicon controlled rectifiers (SCRs) for rectification. A phase control circuit with voltage feedback controls the conduction period of the SCRs to regulate the output voltage of the module.

The amount of power processed by each 12-pulse module determined the diode voltage and current ratings and the maximum transformer size desired for the power processor. Based on preliminary radiation tests conducted for Project Prometheus, $1200 \mathrm{~V}$ was the maximum voltage rating on the

diodes selected for the Prometheus-1 application. To maintain a reasonable transformer size, single-phase transformers were chosen and maximum power was limited to $1500 \mathrm{~W}$. Although the frequency for the Prometheus PCAD system was selected to be $2.25 \mathrm{kHz}$, the transformers of the power processor were designed for $2.0 \mathrm{kHz}$ because this was the maximum frequency of the lab AC power supply used to feed the input to the power processor for testing.

The beam supply was built using four unregulated and one regulated rectification modules with their outputs connected in series to generate $6500 \mathrm{~V}$. A schematic diagram of the beam supply is shown in Figure 4 and photographs of regulated and unregulated modules are shown in Figure 3.

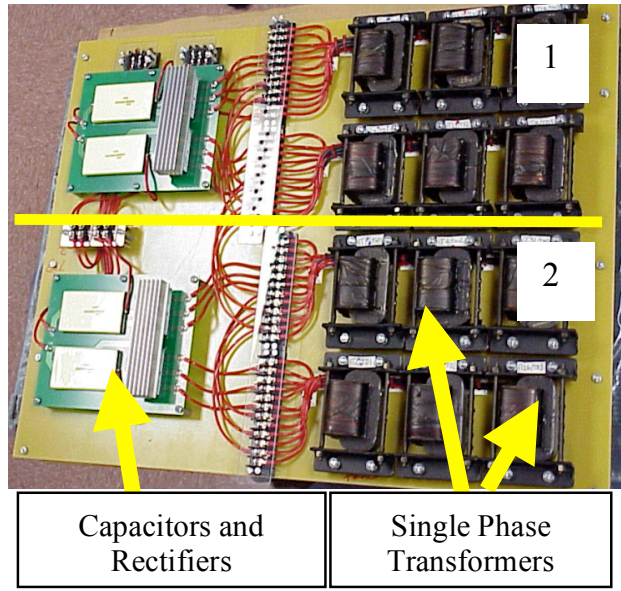

a) Unregulated (x2)

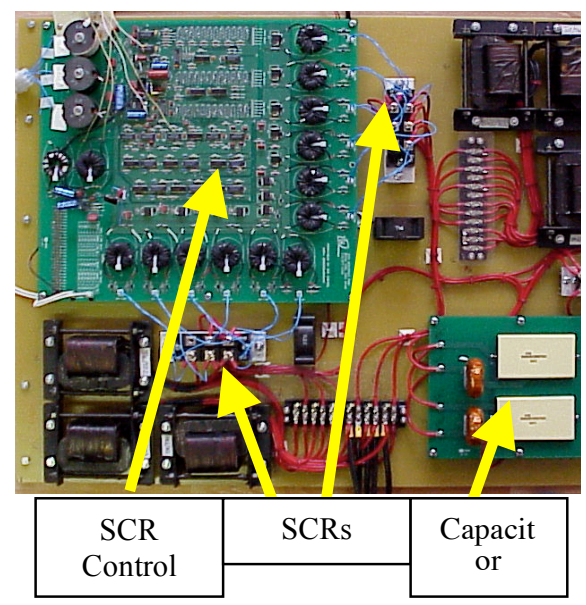

b) Regulated

Figure 3. Beam modules 
Short circuit protection for recycle control was implemented to protect both thruster and power processor. When an output current sensor detects a current that exceeds a threshold, the AC input to the beam supply is disconnected from the input bus. After a predetermined amount of time, power is reapplied to the beam supply restoring steadystate conditions. The primary switching function was originally implemented and successfully tested with triacs. Subsequently, it was redesigned and tested with high voltage MOSFETs, since after the radiation tests triacs were deemed unsuitable for the Prometheus-1 application.

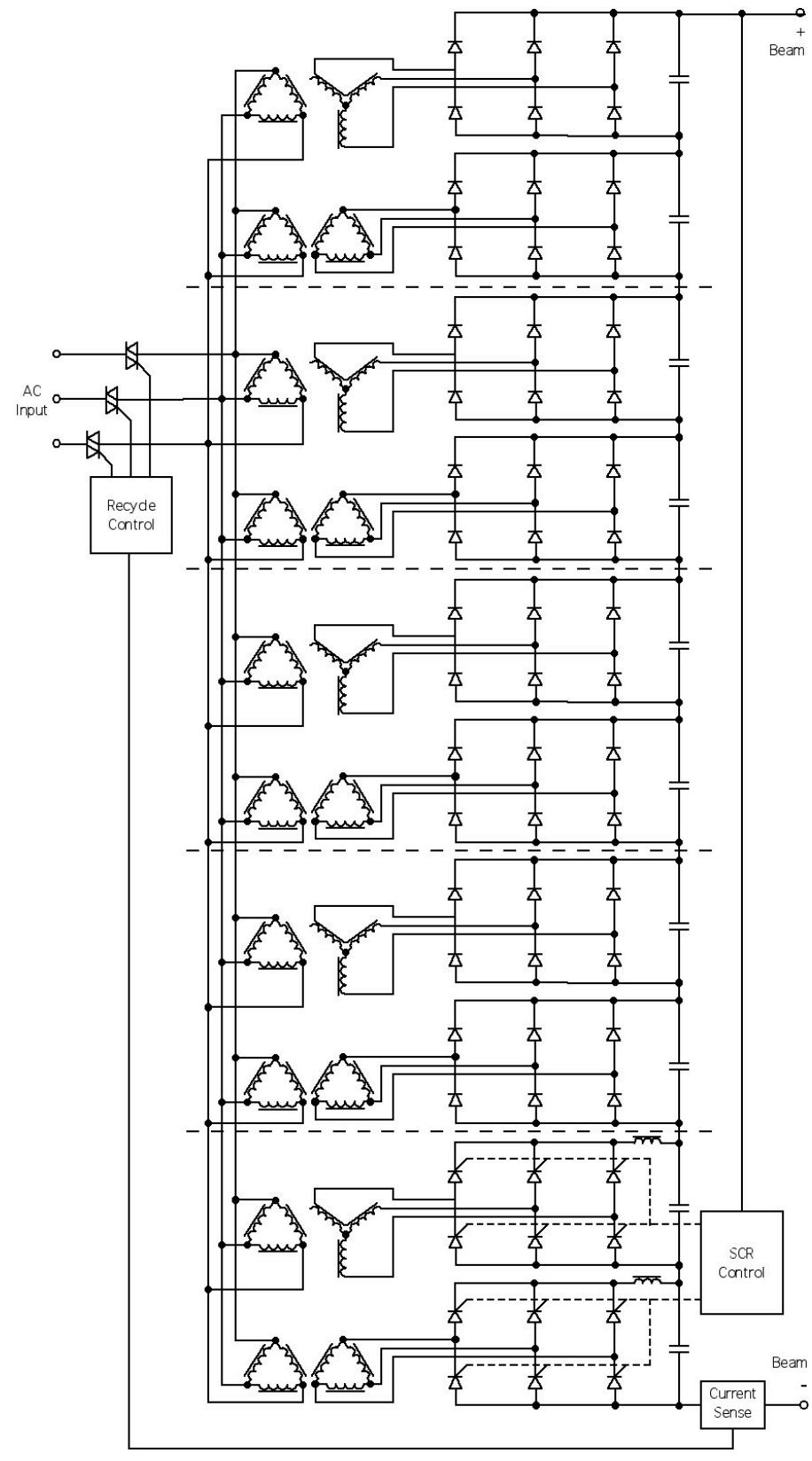

Figure 4. Schematic of the Prometheus-1 beam supply

\section{Beam Supply Test Results}

The beam supply was tested to verify input and output requirements, efficiency, regulation, output voltage ripple and fault protection. The input to the beam supply was provided by a $30 \mathrm{kVA}$ laboratory AC power source. Line inductors of $125 \mathrm{mH}$ were installed on the output of the AC power source to simulate the effect of the output impedance of the permanent magnet alternator of the Brayton power conversion system. Testing was limited to approximately $17.5 \mathrm{~kW}$ of power because of the current limit on the AC power source. A full output voltage of $6500 \mathrm{~V}$ was demonstrated but a lower output current to limit the input current. Additional efficiency testing was conducted on individual modules operated at full power conditions. A higher power source to do full power testing was procured but was not received in time to include the results in this report. The thruster load was simulated using a high power resistive load that included a high voltage relay that could be manually controlled to simulate thruster short circuits.

\section{A. Performance}

The beam supply was tested for efficiency, regulation and output ripple using a resistive load. The input to the beam supply was measured with a high bandwidth, 3-phase power meter while the output was measured using digital multi-meters and a high voltage probe. Because of the power limitation of the AC source, measurements were done on individual 12-pulse regulated and unregulated modules for a nominal output voltage of approximately $1300 \mathrm{~V}$ per module. Table 2 shows the results of these tests. As expected the unregulated module demonstrated higher efficiency than the regulated module because of additional losses from switching the SCRs and the firing angle where it operates.

The efficiency of these modules was slightly lower than expected. After some analysis it was determined that the transformers could be improved by using larger wire for both primary and secondary windings to minimize copper losses. It was estimated the approximately 1 percent increase in efficiency is possible. This will be addressed on the second version of the beam supply.

A complete beam supply with four unregulated, one regulated module and fault protection circuitry was also tested for efficiency and regulation at a power level of $17.5 \mathrm{~kW}$. At an input voltage of $400 \mathrm{Vac}$ and an output of $6500 \mathrm{~V}$ the efficiency was 94.8 percent. This is lower than previously measured on the individual modules because the triacs used for fault protection introduced an additional power loss. The unit demonstrated a line regulation of 
$1.0 \%$ when tested for line regulation by measuring the output voltage through the complete input voltage range of 360 to 440 Vac.

Table 2. Efficiency of Beam Modules

\begin{tabular}{|c|c|c|c|c|}
\hline $\begin{array}{c}\text { Input Voltage } \\
\text { (Vac }_{\text {L-L }} \text { ) }\end{array}$ & $\begin{array}{c}\text { Output } \\
\text { Voltage } \\
\text { (Vdc) }\end{array}$ & $\begin{array}{c}\text { Output } \\
\text { Current } \\
\text { (Adc) }\end{array}$ & $\begin{array}{c}\text { Output } \\
\text { Power (W) }\end{array}$ & $\begin{array}{c}\text { Efficiency } \\
(\%)\end{array}$ \\
\hline $\begin{array}{c}\text { Unregulated } \\
\text { Module }\end{array}$ & & & & \\
\hline 380 & 1353 & 3.56 & 4817 & 96.3 \\
\hline 400 & 1423 & 3.75 & 5336 & 96.3 \\
\hline 420 & 1497 & 3.94 & 5898 & 96.4 \\
\hline $\begin{array}{c}\text { Regulated } \\
\text { Module }\end{array}$ & & & & \\
\hline 380 & 1329 & 3.39 & 4505 & 95.8 \\
\hline 400 & 1336 & 3.66 & 4890 & 95.3 \\
\hline 420 & 1345 & 3.84 & 5165 & 95.1 \\
\hline
\end{tabular}

Figure $5 \mathrm{~b}$ shows the input current captured after the in-line inductors at nominal input voltage and $17.5 \mathrm{~kW}$ output power. This waveform shows that even with the SCR and diode switching, the 12-pulse rectification results in a very sinusoidal input current with very small distortion. Figure $5 \mathrm{~b}$ shows the output voltage and current traces. An output ripple of 4.2 percent was measured at these conditions. Notice that the output ripple has a higher frequency than the fundamental input frequency because of the 12-pulse rectification.

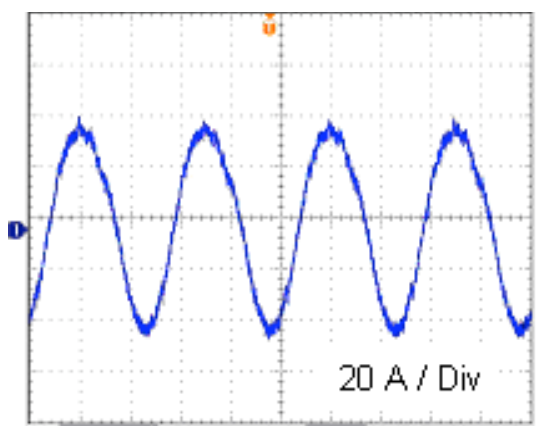

a) Beam supply input current, single phase $(400 \mu \mathrm{s} / \mathrm{div})$

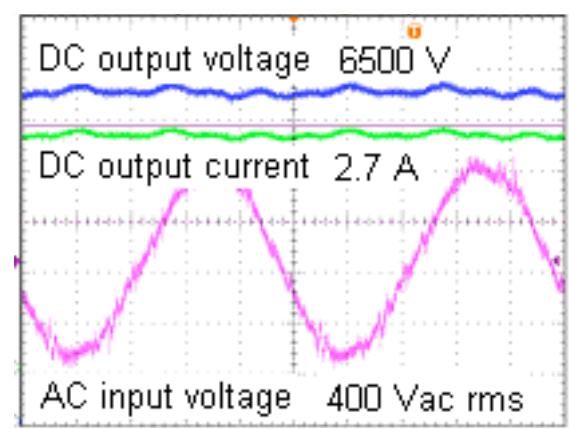

b) Beam supply input voltage and
output $(200 \mu \mathrm{s} /$ div $)$

Figure 5. Beam supply waveforms

\section{B. Recycles}

The beam supply includes a fault recovery or recycle circuit to protect both the ion thruster and power processor from short circuit faults on the thruster grids. In the NSTAR and NEXT PPUs, the beam supply consisted of DCDC converters. Therefore, recycle protection was implemented using the primary current limit function of the DCDC converters. Because of the transformer/rectifier modules used for the Prometheus-1 beam supply, recycle protection is implemented by semiconductor switches on the primary side of the transformers due to the lower operating voltage. Originally, triacs were chosen for this function because they were available for high blocking voltages and currents. Also, the forward drop of these devices would result in low conduction losses compared to other high voltage devices.

Because of failures in radiation tests, triacs were no longer favored for this function so the recycle circuitry was also tested using $1000 \mathrm{~V}$ MOSFETs. An additional loss in efficiency of 1.2 percent was observed because of the 
high on-resistance of these particular high voltage MOSFETs. Although these devices are unlikely to pass Prometheus-1 radiation requirements, other low voltage MOSFET are expected to pass. Testing was conducted with the high voltage MOSFETs to validate the approach. To properly use MOSFETs for this function, multiple lower voltage devices, with good radiation properties, have to be connected in series to provide enough blocking voltage. Even though lower voltage devices will have lower individual on-resistance and conduction losses, having multiple in series will have a high net loss comparable to the high voltage devices.

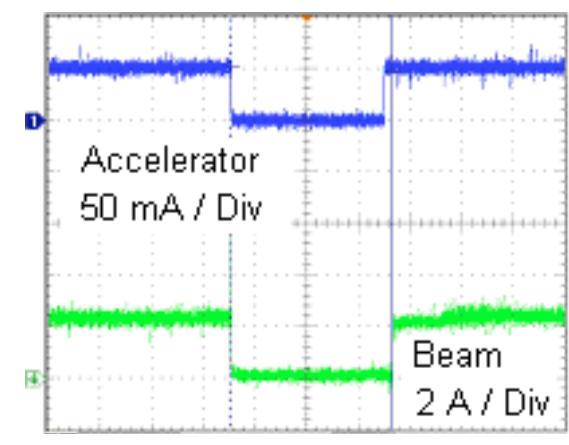

a) $200 \mathrm{~ms} / \mathrm{div}$

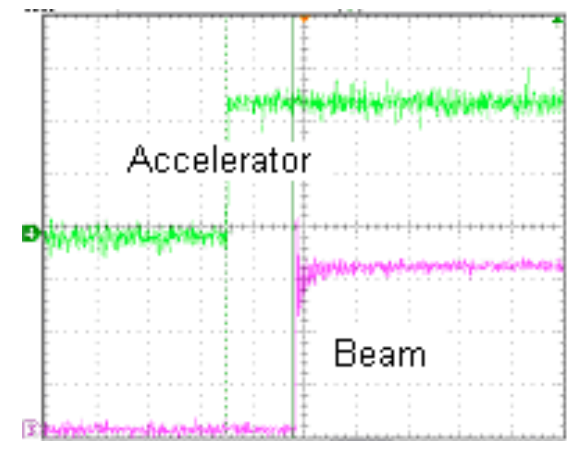

b) $20 \mathrm{~ms} / \mathrm{div}$

Figure 6. Recycle timing for beam and accelerator supplies

Recycle testing was conducted using the complete beam supply and the accelerator supply power with its own transformer/rectifier module. The accelerator supply was included in recycle testing for several reasons. First, it is in the current path when a grid-to-grid recycle occurs. Second, the timing of the accelerator supply relative to the beam supply is critical for recycles. Finally, it was included to verify that there were no interactions between the beam and accelerator supplies operating from the same input source. The beam supply was operating at full power and the accelerator supply was operated at maximum and nominal power. The beam and accelerator supplies were connected as they would be in a power processor with the negative side of the beam supply connected to the positive side of the accelerator supply. Then, recycles were simulated by repeatedly shorting the positive output of the beam supply to the negative output of the accelerator supply.

Figure 6a show the output of the beam and accelerator supplies during a recycle. When a short circuit occurs, the recycle protection circuit senses the output current of the beam supply and triggers when the current exceeds a threshold value. The circuit must immediately turn-off the beam and accelerator supplies and reduce or "cutback" the discharge current. After the fault is extinguished and everything is discharged, high voltage is restored. The accelerator supply must be turned on before the beam to preclude electron back-streaming that can extinguish or damage the discharge cathode. Figure $6 \mathrm{~b}$ shows that the accelerator supply leads the beam supply by approximately $30 \mathrm{~ms}$. Then, the discharge supply is restored to nominal conditions $100 \mathrm{~ms}$ after the high voltage reaches steady-

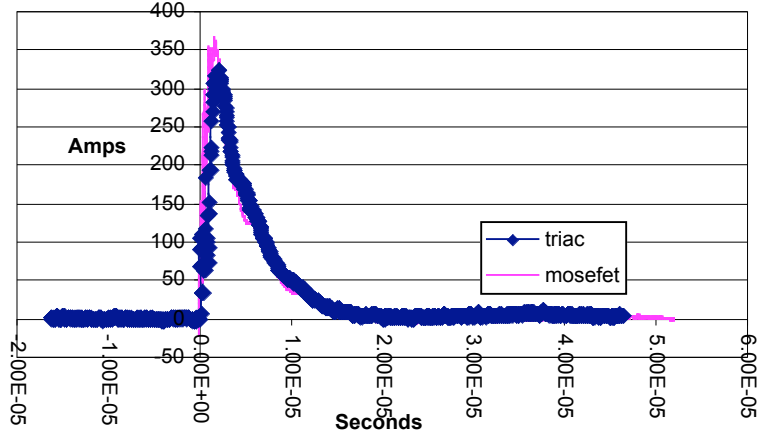

Figure 7. Beam fault current during simulated recycle (50A/div and $10 \mu \mathrm{s} / \mathrm{div})$ state conditions. All recycle parameters including current threshold, off time and delays can be adjusted to meet requirement changes.

\section{Stored Charge}

The regulated and unregulated beam modules have a $1 \mu \mathrm{F}$ capacitor on their outputs to reduce voltage ripple. In a complete beam supply, these capacitors store a total charge of $650 \mu \mathrm{C}$ and an energy of $2.11 \mathrm{~J}$. Additionally, energy is stored in the magnetizing and leakage inductance of the transformers. During a recycle, since the primary side of the beam supply is disconnected from the power source by semiconductor switches, the charge stored in both capacitors and transformers is transferred to the ion thruster grids. In addition, 
since during a recycle the primary side of the beam supply is disconnected by semiconductor switches, energy in the magnetizing and leakage in inductances of the transformers can only be dissipated into the output increasing the total charge transferred to the thruster grids.

Testing was conducted to measure the amount of charge that the breadboard beam supply transferred into a gridto-grid short circuit. A current probe was used to measure the output current during a simulated recycle. Testing was conducted with both triacs and MOSFETs to compare their switching performance. Figure 7 shows the typical waveforms obtained in this test. No significant difference was observed between triacs and MOSFETs however, large snubbers were required on the triacs because larger turn-off oscillations were observed. Integrating the waveform in Figure 7 resulted in a total charge of $1.8 \mathrm{mC}$ with triacs and $1.7 \mathrm{mC}$ with MOSFETs. Even though testing is necessary to determine the maximum charge transfer requirement for the Herakles ion thruster, the value obtained for the Prometheus-1 power processor is within an order of magnitude of requirements for prior programs.

\section{Ancillary Supplies}

\section{A. Discharge Supply}

The discharge power supply operates in current mode at a maximum output power of $1.82 \mathrm{~kW}$. The output voltage and current ranges are 15-35 Vdc and 15-52 A, respectively. A full bridge topology, shown in Figure 8, was selected due to the high power and efficiency requirements. In this topology, diagonal MOSFETs are controlled in alternating half cycles applying a bi-directional excitation to the power transformer. This results in complete use of the hysteresis of the core and a smaller and more efficient transformer. Another advantage of the full-bridge topology is that switching transients are clamped to the input bus and the transistors are only stressed to the input voltage level. A switching frequency of $100 \mathrm{kHz}$ was selected based on a trade-off between size of magnetic components and efficiency. A center-tapped secondary with a full-wave rectifier using Schottky diodes at the output was implemented to minimize losses. Also, the output voltage of the rectifier has twice the switching frequency, reducing the size of the output inductor.

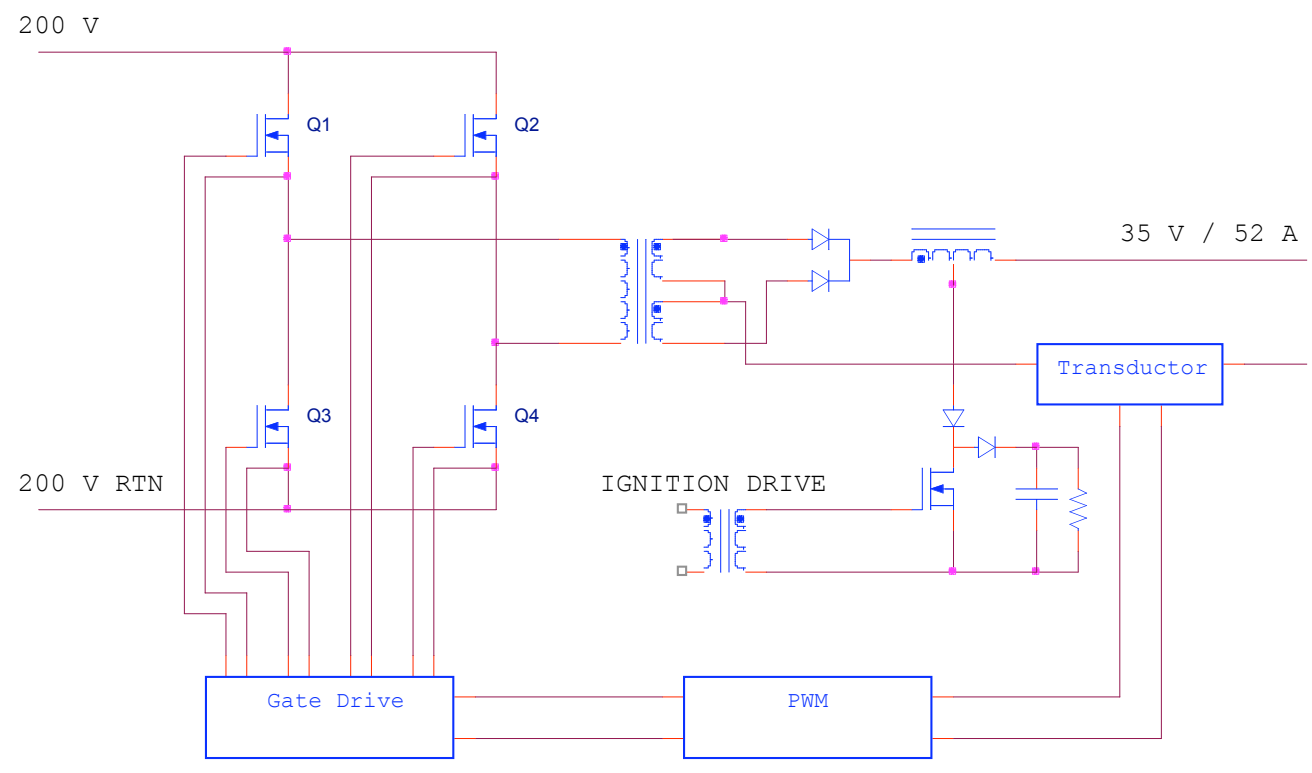

Figure 8. Discharge Supply Simplified Schematic

One disadvantage of this topology is susceptibility to shoot-through related faults. ${ }^{4}$ A shoot-through occurs whenever switches of the same leg (such as Q1 and Q3 in Figure 8) are simultaneously turned on, causing a short circuit on the input bus. This results in a high current through the MOSFETS and a possible failure of the converter. Many safe guards were built into the design to preclude shoot through faults. Particular care was taken to assure that the gate drives to the MOSFETS are carefully routed and transformer gate drives were used to provide a bipolar gate 
signal that quickly turns off the MOSFETS. Finally, circuitry was included to quickly discharge the Miller capacitance of the MOSFETS.

Also shown in Figure 8 is the igniter circuitry that generates a high voltage pulse to help start the discharge cathode using the same design as NSTAR and NEXT PPUs. A MOSFET is turned on to allow current flow through the output inductor center-tap storing energy. The MOSFET is then quickly turned-off forcing the stored energy to be released in the form of a high voltage pulse.

Figure 9 shows a photograph of the breadboard discharge supply. The large printed circuit board (PCB) holds all the power components to which a

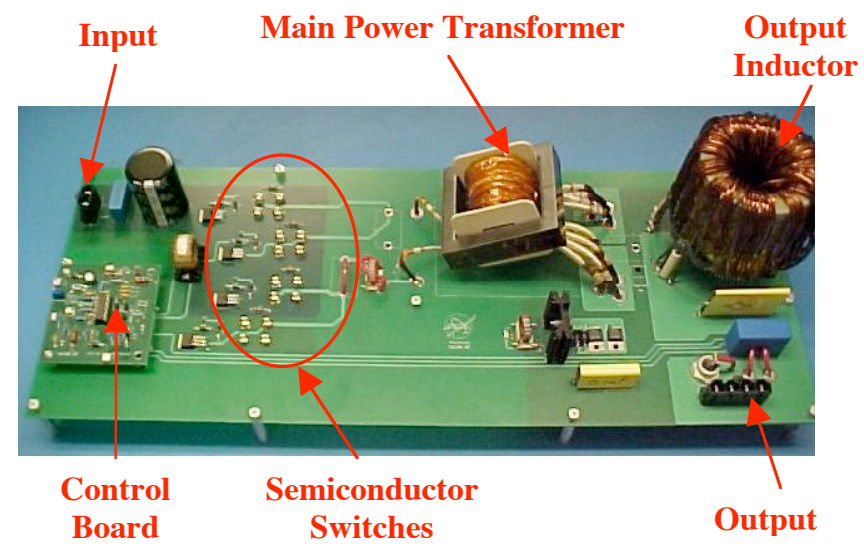

Figure 9. Breadboard discharge supply Board smaller PCB containing the control circuitry is connected. The supply has been successfully tested to full power with efficiencies ranging between $85-91 \%$, depending on the power output level. The output current ripple was measured between $4-5 \%$ and line regulation was better than $2 \%$. The total weight of the unit is approximately 4.5 $\mathrm{kg}$. The discharge supply met all performance requirements and mass estimates.

\section{B. Neutralizer Keeper and Heater Supplies}

The neutralizer keeper, discharge heater, and neutralizer heater supplies operate at an output power of less than $220 \mathrm{~W}$. For these low power supplies a half-bridge topology was implemented due to design simplicity, only requiring two MOSFETS to operate, while still maintaining good transformer utilization. Figure 10 is a simplified power schematic of these supplies. Similarly to the discharge supply, the switching frequency was selected to be 100 $\mathrm{kHz}$. The breadboard layout for these supplies is similar in nature to the discharge supply. One printed circuit board (PCB) will be used for the power magnetic components and MOSFETS, while a smaller PCB for PWM control plugs into the former. These supplies utilize many of the same features as the full bridge discharge supply, including input power level, the gate drive scheme and output Schottky rectifiers.

Like the discharge supply, the neutralizer keeper supply includes an high voltage pulse ignitor circuit which is enclosed by the dashed line in figure 16 . The breadboards are anticipated to minimally be one quarter the size of the discharge supply.

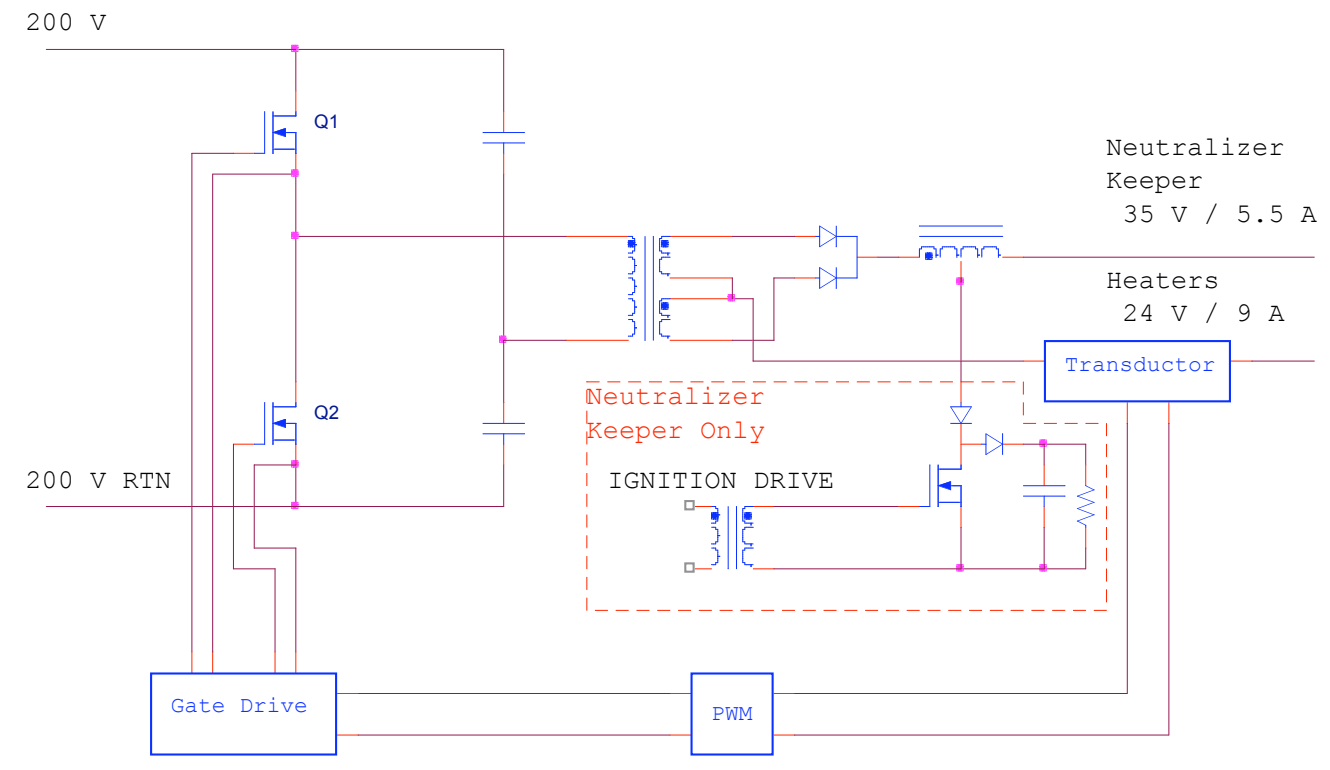

Figure 10. Neutralizer keeper and heater supply simplified schematic 


\section{Redesigned Beam Supply}

A second version of the beam supply was developed because the semiconductor selected for the first version were deemed unsuitable for the radiation environment for the Prometheus-1 application and the operating frequency of the PCAD system was increased from 1.00 to $2.25 \mathrm{kHz}$. A new approach was needed to regulate voltage and eliminate the SCRs and to switch the primary of the beam supply to eliminate the triacs or high voltage MOSFETs because of efficiency concerns.

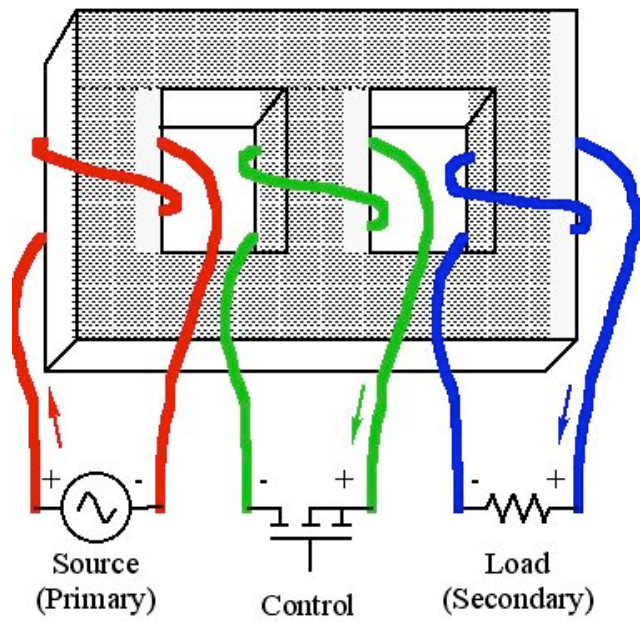

Figure 11. Beam electrically regulated transformer concept

While experimenting with magnetic amplifiers for primary switching, the idea of combining their functionality with the transformer was suggested. The result was called a beam electrically regulated transformer (BERT) which operates as a transformer and also is capable of controlling the input. Figure 11 shows the basic concept of BERT that consists of a transformer with a additional control magnetic path where a control winding is added. A MOSFETs connected to the control winding is used to open or short circuit the control winding. When the MOSFET is open, the control leg is a path a low reluctance that diverts the magnetic flux from the primary and prevent it from flowing through the secondary leg and inducing voltage on the secondary winding. When the MOSFET closed, the control leg becomes a high reluctance path because the high current flowing through the control winding induces a flux that opposes the primary flux from going through the control leg. As a result, all the magnetic flux induced by the primary flows through the secondary leg inducing voltage on the secondary winding.

The most significant advantage of the BERT concept for the Prometheus-1 application is that switching is done at the control winding and the voltage can be selected by the primary to control turns ratio. This allows using low voltage MOSFETs that are readily available in radiation hardened versions.

A full scale BERT was built and tested for efficiency. A custom built low-profile ferrite core was used to increase the potential radiation shielding area of the transformer. An efficiency of $98.2 \%$ was demonstrated at full power condition of $1.5 \mathrm{~kW}$ and an input of $400 \mathrm{Vac}$. The high efficiency is result of a winding design that maximizes coupling and because very little power is dissipated in the control winding when the transformer is turned on.

A complete beam supply using BERT modules is currently in fabrication. A total of four 12-pulse modules will be used. The output voltage of the modules will be regulated by phase control on the control MOSFETs. These will also shutdown the beam supply when a recycle occurs.

\section{Conclusion}

A breadboard power processor for the Prometheus-1 application was designed, fabricated and tested on resistive loads. The first version of the beam supply consists of 12-pulse, regulated and unregulated transformer/rectifier modules that operate of the 3-phase 400 Vac input. Recycle protection was implemented by switching the primary side of the transformers with triacs. Full power performance was demonstrated on individual modules and with the complete beam supply at $17.5 \mathrm{~kW}$. The efficiency measured was 94.8 percent.

The ancillary supplies were designed with DC-DC converters fed by an additional transformer/rectifier module. The discharge supply consists of a full-bridge converter while the neutralizer keeper, the accelerator and the two heater supplies consists of a half-bridge converter. All converters operate at a switching frequency of $100 \mathrm{kHz}$.

An second version of the beam supply was designed to only using suitable power semiconductors for the possible radiation environments for Prometheus-1. The beam modules were designed using a electrically regulated transformer that provided voltage regulation and recycle control by steering magnetic flux in the transformer core using low voltage MOSFETs on a control winding. These transformers were built and demonstrated an efficiency of 98.2 percent and excellent switching performance. A complete beam supply will be built using this design and integrated with the ancillary supplies to finish the power processor. 
This power processor technology work validated a design that can potentially meet all the stringent environmental requirements of Prometheus-1. A complete breadboard power processor will be fabricated and integrated with a laboratory Herakles ion thruster.

\section{References}

${ }^{1}$ Hamley, J. A., et al., "The Design and Performance Characteristics of the NSTAR PPU and DCIU," AIAA-98-3938, Joint Propulsion Conference, Cleveland, OH, July 20-23, 1998.

${ }^{2}$ Phelps, T. K., Wiseman, S., Komm, D. S., Bond, T., Pinero, L. R., "Development of the NEXT Power Processing Unit," AIAA-2003-4867, Joint Propulsion Conference, Huntsville, AL, July 20-23, 2003.

${ }^{3}$ Oleson, S., Elliot, F., Randolph, T. and Dipprey, N., "The Electric Propulsion Segment of Prometheus 1," AIAA-20053888, Joint Propulsion Conference, Tucson, AZ, July 10-13, 2005.

${ }^{4}$ Patterson, M., Elliot, F., Malone, S., Soulas, G., Goebel, D., Sengupta, A., "Herakles Thruster Development for the Prometheus JIMO Mission,” AIAA-2005-3890, Joint Propulsion Conference, Tucson, AZ, July 10-13, 2005.

${ }^{5}$ Randolph, T., "The Prometheus 1 Spacacraft Preliminary Electric Propulsio System Design," AIAA-2005-3889, 41 ${ }^{\text {st }}$ Joint $^{2}$ Propulsion Conference, Tucson, AZ, July 11-14, 2005.

${ }^{6}$ Scina, Joseph, Aulisio, Michael, Gerber, Scott, Hewitt, Frank, Miller, Leonard, Pinero, Luis and Elbuluk, Malik, "Power Processing for a Conceptual Project Prometheus Electric Propulsion System," AIAA-2004-3452, Joint Propulsion Conference, Fort Lauderdale, FL, July 11-14, 2004.

${ }^{7}$ Mason, L., “A Power Coversion Concept for the Jupiter Icy Moons Orbiter," AIAA Journal of Propulsion and Power, Volume 20, Number 5, Pages 902-910.

${ }^{8}$ Hervol, D., Mason, L., Birchenough, A. and Pinero, L., "Experimental Investigation from the Operation of a 2kW Brayton Power Conversion Unit and a Xenon Ion Thruster," Space Technology and Applications International Forum, Albuquerque, NM, February 8-12, 2004.

${ }^{9}$ Goebel, Dan M., and Schneider, Analyn C., "High Voltage Breakdown and Conditioning of Carbon and Molybdenum Electrodes," IEEE Transactions on Plasma Science, September 2004. 
Public reporting burden for this collection of information is estimated to average 1 hour per response, including the time for reviewing instructions, searching existing data sources, gathering and maintaining the data needed, and completing and reviewing the collection of information. Send comments regarding this burden estimate or any other aspect of this collection of information, including suggestions for reducing this burden, to Washington Headquarters Services, Directorate for Information Operations and Reports, 1215 Jefferson Davis Highway, Suite 1204, Arlington, VA 22202-4302, and to the Office of Management and Budget, Paperwork Reduction Project (0704-0188), Washington, DC 20503.

\begin{tabular}{|l|l|l}
\hline 1. AGENCY USE ONLY (Leave blank) & $\begin{array}{c}\text { 2. REPORT DATE } \\
\text { May } 2006\end{array}$ & $\begin{array}{r}\text { 3. REPORT TYPE AND DATES COVERED } \\
\text { Technical Memorandum }\end{array}$
\end{tabular}

\section{TITLE AND SUBTITLE} 5. FUNDING NUMBERS

Status of a Power Processor for the Prometheus-1 Electric Propulsion System

\section{AUTHOR(S)}

WBS-22-973-10-48

Luis R. Piñero, Gerald M. Hill, Michael Aulisio, Scott Gerber, Elmer Griebeler,

Frank Hewitt, and Joseph Scina

\section{PERFORMING ORGANIZATION NAME(S) AND ADDRESS(ES)}

National Aeronautics and Space Administration

John H. Glenn Research Center at Lewis Field

Cleveland, Ohio 44135-3191

8. PERFORMING ORGANIZATION REPORT NUMBER

E-15305

\section{SPONSORING/MONITORING AGENCY NAME(S) AND ADDRESS(ES)}

National Aeronautics and Space Administration

Washington, DC 20546-0001
10. SPONSORING/MONITORING AGENCY REPORT NUMBER

NASA TM-2006-213983

AIAA-2005-3895

\section{SUPPLEMENTARY NOTES}

Prepared for the 41st Joint Propulsion Conference and Exhibit cosponsored by AIAA, ASME, SAE, and ASEE, Tucson, Arizona, July 10-13, 2005. Luis R. Piñero and Gerald M. Hill, NASA Glenn Research Center; and Michael Aulisio, Scott Gerber, Elmer Griebeler, Frank Hewitt, and Joseph Scina, ZIN Technologies, Inc., 3000 Aerospace Parkway, Brook Park, Ohio 44142. Responsible person, Luis R. Piñero, organization code RPP, 216-977-7428.

\begin{tabular}{|l|l}
\hline 12a. DISTRIBUTION/AVAILABILITY STATEMENT & 12b. DISTRIBUTION CODE
\end{tabular}

Unclassified - Unlimited

Subject Category: 20

Available electronically at http://gltrs.grc.nasa.gov

This publication is available from the NASA Center for AeroSpace Information, 301-621-0390.

\section{ABSTRACT (Maximum 200 words)}

NASA is developing technologies for nuclear electric propulsion for proposed deep space missions in support of the Exploration initiative under Project Prometheus. Electrical power produced by the combination of a fission-based power source and a Brayton power conversion and distribution system is used by a high specific impulse ion propulsion system to propel the spaceship. The ion propulsion system include the thruster, power processor and propellant feed system. A power processor technology development effort was initiated under Project Prometheus to develop high performance and lightweight power-processing technologies suitable for the application. This effort faces multiple challenges including developing radiation hardened power modules and converters with very high power capability and efficiency to minimize the impact on the power conversion and distribution system as well as the heat rejection system. This paper documents the design and test results of the first version of the beam supply, the design of a second version of the beam supply and the design and test results of the ancillary supplies.

\section{SUBJECT TERMS}

Electric propulsion; Power electronics; Power processing unit; Ion thrusters

\begin{tabular}{|c|c|}
\hline $\begin{array}{c}\text { 17. SECURITY CLASSIFICATION } \\
\text { OF REPORT } \\
\text { Unclassified }\end{array}$ & $\begin{array}{c}\text { 18. SECURITY CLASSIFICATION } \\
\text { OF THIS PAGE } \\
\text { Unclassified }\end{array}$ \\
\hline
\end{tabular}

19. SECURITY CLASSIFICATION
OF ABSTRACT
Unclassified

Standard Form 298 (Rev. 2-89)

Prescribed by ANSI Std. Z39-18 298-102 

